\title{
José Baselga M.D., Ph.D. (1959-2021) leading cancer researcher and oncologist
}

\author{
Moshe Elkabets $^{1 *}$ and Giovanni Blandino $2^{2^{*}}$
}

On March 21st, 2021, one of the most remarkable leaders in oncology Dr. José Baselga - friend, colleague and mentor - passed away before his time. The entire cancer research and oncology community was shocked by the premature death of José, who for three decades led the therapeutic revolution towards personalized/precision medicine using targeted therapies. Josés ability to envisage treatment in the years ahead led him to become one of the best-known leaders in drug development in medical oncology.

At the age of 27, after graduation from the University of Autonoma de Barcelona, military service duty, and a year of residency at Vall d'Hebron hospital in Barcelona, José moved to New York to start his career as a breast cancer oncologist and researcher. By day, José dedicated his time to treating cancer patients at Kings County Hospital in Brooklyn and by night and on holidays, to exploring new treatments in the lab at Memorial Sloan Kettering (MSK). José was especially intrigued by the molecular mechanisms of the response to anti-cancer therapies, and this curiosity and hunger for knowledge accompanied him throughout his extraordinary career.

In 1989, at the age of 30, José moved to MSK to work in the clinic with Larry Norton and in the laboratory with John Mendelsohn to investigate the anti-tumor activity of therapies that block the epidermal growth factor receptor (EGFR) and HER2 on cancer cell lines. In the lab, José demonstrated the relevance of blocking EGFR in lung and breast cancer [1-3], and in a work that was published in JNCI 1993, he provided the rationale for combining an anti-EGFR antibody therapy (cetuximab)

\footnotetext{
*Correspondence: moshee@bgu.ac.il; giovbland@gmail.com

${ }^{1}$ The Shraga Segal Department of Microbiology, Immunology and Genetics Faculty of Health Sciences, Ben-Gurion University of the Negev, Beer-Sheva 84105, Israel

${ }^{2}$ Oncogenomic and Epigenetic Unit, IRCCS, Regina Elena National Cancer Institute, Rome, Italy
}

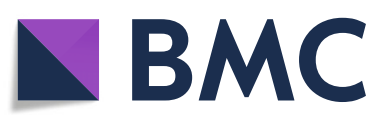

(C) The Author(s). 2021 Open Access This article is licensed under a Creative Commons Attribution 4.0 International License, which permits use, sharing, adaptation, distribution and reproduction in any medium or format, as long as you give appropriate credit to the original author(s) and the source, provide a link to the Creative Commons licence, and indicate if changes were made. The images or other third party material in this article are included in the article's Creative Commons licence, unless indicated otherwise in a credit line to the material. If material is not included in the article's Creative Commons licence and your intended use is not permitted by statutory regulation or exceeds the permitted use, you will need to obtain permission directly from the copyright holder. To view a copy of this licence, visit http://creativecommons.org/licenses/by/4.0/ The Creative Commons Public Domain Dedication waiver (http://creativecommons.org/publicdomain/zero/1.0/) applies to the data made available in this article, unless otherwise stated in a credit line to the data.

with chemotherapy. In addition, he demonstrated, in the lab, how overexpression of HER2 limited the efficacy of chemotherapies in breast cancer [4,5]. As a resident, José led many clinical trials and showed the potential of targeting HER2 in breast cancer patients with HER2 overexpression and of targeting EGFR using cetuximab in EGFR-overexpressing tumors [6-8]. José's achievements in designing and running clinical trials and in performing translational research laid down the grounds for his subsequent career as a prominent oncologist and drug developer.

In 1996, José became the Chairman of Medical and Radiation Oncology and Hematology at Vall d'Hebron Hospital in his hometown, Barcelona, and ten years later, he founded the Vall d'Hebron Institute of Oncology (VHIO). As a director of VHIO, José furthered his vision of promoting translational research by building the bedto-bench culture. To this end, he hired extremely talented basic researchers, supervised them to become translational researchers, and trained medical oncologists to deliver science-driven trials. Joan Albanell, Miguel Angel Molina and José Tabernero were a few of many talented first generation of mentees who worked with José at Vall d'Hebron. The impressive clinical and translational research activities at VHIO built the reputation of the center and that of José in concert. Between 2000 and 2010, José led or was involved in over 110 publications of Phase I and Phase II studies and 17 publications of Phase III studies. Among others, worth mentioning are four published in the New England of Medicine on therapy combinations with anti-HER2 or cetuximab in breast and head and neck cancers, respectively-combinations that were later approved by the FDA [9-12] and saved the lives of thousands of cancer patients. José was always at the frontline of research on new molecular targets, and in addition to anti-EGFR and HER2 therapies he became interested in those blocking 
the PI3K/mTOR pathway, which regulates tumor progression. Side by side with the development of pan-PI3K/ mTOR inhibitors in the clinic, José nurtured a second generation of translational investigators, among them Maurizio Scaltriti and Violeta Serra. The research team in Barcelona worked to elucidate mechanisms of resistance to anti-HER2 and PI3K therapies and demonstrated novel concepts of re-activation of survival signaling pathways [13-18]. Their findings provided the rationale for testing therapeutic combinations such as concomitant PARP and PI3K inhibition. On the clinical side, José was involved in the training of accomplished oncologists like Jordi Rodon, Cristina Saura, and Javier Cortes.

In early 2000 Josè was a member of the International Advisory Board of Regina Italian National Cancer Institute in Rome and his unique scientific impetous led to the implementation of Disease Team Management. Their multidisciplinary approach is fundamental for the transational and clinical management that rountinely we offer to admitted patients.

After 14 years at Vall d'Hebron, José accepted the position of Chief of Hematology and Oncology at Massachusetts General Hospital (MGH) in Boston. For this next challenge, José encouraged Maurizio Scaltriti to become a Harvard Medical School instructor and build his lab from scratch. At MGH, José and Maurizio recruited the third generation of translational investigators, whose primary focus was to uncover mechanisms of response and resistance to isoform-specific PI3K inhibitors. On the clinical side, Dejan Juric led the clinical development. José, in his charismatic and elegant way, encouraged all group members to join forces and expertise to test anti-PI3K agents in pre-clinical models and to validate the findings in cancer patients [19-22]. The studies generated by José's lab, together with those of other outstanding leaders in the field, such as Carlos Arteaga, Gordon Mills, Lew Cantley, Jeffery Engelman, Neal Rosen, and Levi Garraway, provided molecular insight on the effectiveness of and resistance to these agents in PIK3CA-mutated solid cancers.

In January 2013, José was recruited at Memorial Sloan Kettering Cancer Center (MSKCC) as Physician-in-Chief and relocated his lab to that institution. At MSKCC, José expanded the research on isoform-specific PI3K inhibitors into epigenetics [2326] and into other pathologies, such as head and neck cancers and venous malformations [27-29]. During the almost 6 years at MSK, José chalked up a few major milestones, including the establishment of the Center for Molecular Oncology (CMO), Early Drug Development Services led by the talented David Hyman. He wanted - and obtained - an in-house targeted genomic sequencing platform (MSK-IMPA $\mathrm{CT}$ ), which would broaden therapeutic alternatives for cancer patients, as it would enable cancer patients to enroll in basket trials based on genomic alterations their cancers. He was thus involved in developing and designing of several basket trials and reinforced the importance of genomic-driven medicine in medical oncology [30-33]. By virtue of these efforts, genomic sequencing and precision medicine became the norm for most cancer patients at MSKCC. The entire scientific community, and José's research group as part of it, benefited from the massive genomic sequencing information generated at the CMO, and the fourth (and last) generation of translational investigators utilized these data to focus on the underlying role of specific genomic alterations in the response and resistance to multiple treatments in cancer patients $[24,34,35]$.

In 2017, Josè was awarded with the Lombroso Prize at the Weizmann Institute of Science in Israel. His award lecture was outstanding. His unique ability to surf into basic, translational and clinical research captured the audience and instigated a number of questions that lasted over the lunch award ceremony.

In September 2018, José resigned from MSK and joined to AstraZeneca (AZ) as the Executive Vice President of Oncology R\&D, and started to bring an academic view into industry by accelerating clinical trials driven by experimental evidence and by exploring new anti-cancer therapeutics. Moreover, he encouraged the physicians running the clinical trials to collaborate with research scientists to elucidate the individual patient's response to therapy.

Over the past 30 years, José was involved in the development of at least twelve FDA-approved anti-cancer agents. He published around 500 peered review publications and was in a member of Editorial advisory boards of top journals such as Journal of Clinical Oncology and Cancer Cell. He co-founded and led as Editor in Chief Cancer Discovery, now a reference source for the oncology community. José received many awards and served as the president of ESMO and the AACR.

As a mentee, I sincerely appreciate the time and effort José invested in me and in all his mentees, and I cherish his sincere willingness to help in developing the careers of many translational researchers and oncologists. I will always remember his generosity, remarkable sense of humor, and genuine passion for science.

It is with tears and deep sorrow that we extend our deepest condolences to José's family and to all those who were close to him.

Rest in peace my dear friend and mentor.

Moshe Elkabets Ph.D.

Dr. Baselga thank you very much for inspiring future generations with your visionary leadership in translational and medical oncology.

Giovanni Blandino MD. 


\section{Disclosures}

Giovanni Blandino is Deupity Editor of Journal of Experimental \& Clinical Cancer Research.

\section{Authors' contributions}

The authors read and approved the final manuscript.

\section{Competing interests}

The authors declare that they have no competing interests

Published online: 07 May 2021

\section{References}

1. Fan Z, Baselga J, Masui H, Mendelsohn J. Antitumor effect of anti-epidermal growth factor receptor monoclonal antibodies plus cisDiamminedichloroplatinum on well established A431 cell Xenografts. Cancer Res. 1993;53:4637-42.

2. Baselga J, Norton L, Masui H, Pandiella A, Coplan K, Miller WH, et al. Antitumor effects of doxorubicin in combination with anti-epidermal growth factor receptor monoclonal antibodies. J Natl Cancer Inst. 1993;85: 1327-33 [cited 2021 Apr 18]. Available from: https://pubmed.ncbi.nlm.nih. gov/8340945/.

3. Rusch V, Baselga J, Cordon-Cardo C, Orazem J, Aman M, Hoda S, et al. Differential expression of the epidermal growth factor receptor and its ligands in primary non-small cell lung cancers and adjacent benign lung1. 1993.

4. Baselga J, Norton L, Albanell J, Kim Y-M, Mendelsohn J. Recombinant humanized anti-HER2 antibody (Herceptinâç) enhances the antitumor activity of paclitaxel and doxorubicin against HER2/neu overexpressing human breast cancer Xenografts. Cancer Res. 1998;58(13):2825-31.

5. Baselga J, Seidman AD, Peter Rosen P, Norton L. HER2 overexpression and paclitaxel sensitivity in breast cancer: therapeutic implications. Oncology. 1997:43-8 [cited 2021 Apr 18]. Available from: https://europepmc.org/a rticle/med/9110342.

6. Baselga J, Pfister D, Cooper MR, Cohen R, Burtness B, Bos M, et al. Phase I studies of anti-epidermal growth factor receptor chimeric antibody C225 alone and in combination with cisplatin. J Clin Oncol. 2000;18:904-14 [cited 2021 Apr 18]Available from: https://pubmed.ncbi.nlm.nih.gov/10673534/.

7. Pegram MD, Lipton A, Hayes DF, Weber BL, Baselga JM, Tripathy D, et al. Phase II study of receptor-enhanced chemosensitivity using recombinant humanized anti-p185(HER2/neu) monoclonal antibody plus cisplatin in patients with HER2/neu-overexpressing metastatic breast cancer refractory to chemotherapy treatment. J Clin Oncol. 1998;16:2659-71 [cited 2021 Apr 18]. Available from: https://pubmed.ncbi.nlm.nih.gov/9704716/.

8. Baselga J, Tripathy D, Mendelsohn J, Baughman S, Benz CC, Dantis L, et al. Phase II study of weekly intravenous recombinant humanized antip185HER2 monoclonal antibody in patients with HER2/neu-overexpressing metastatic breast cancer. J Clin Oncol. 1996;14:737-44 [cited 2021 Apr 18]. Available from: https://pubmed.ncbi.nlm.nih.gov/8622019/.

9. Verma S, Miles D, Gianni L, Krop IE, Welslau M, Baselga J, et al. Trastuzumab Emtansine for HER2-positive advanced breast cancer. N Engl J Med. 2012; 367:1783-91 [cited 2021 Apr 18]Available from: https://pubmed.ncbi.nlm. nih.gov/23020162/.

10. Bonner JA, Harari PM, Giralt J, Azarnia N, Shin DM, Cohen RB, et al. Radiotherapy plus Cetuximab for squamous-cell carcinoma of the head and neck. N Engl J Med. 2006;354:567-78 [cited 2021 Apr 18]. Available from: http://www.nejm.org/doi/abs/10.1056/NEJMoa053422.

11. Piccart-Gebhart MJ, Procter M, Leyland-Jones B, Goldhirsch A, Untch M, Smith I, et al. Trastuzumab after adjuvant chemotherapy in HER2-positive breast cancer. N Engl J Med. 2005;353:1659-72 [cited 2021 Apr 18]. Available from: https://pubmed.ncbi.nlm.nih.gov/16236737/.

12. Slamon DJ, Leyland-Jones B, Shak S, Fuchs H, Paton V, Bajamonde A, et al. Use of chemotherapy plus a monoclonal antibody against HER2 for metastatic breast cancer that overexpresses HER2. N Engl J Med. 2001;344: 783-92 [cited 2021 Apr 18]. Available from: https://pubmed.ncbi.nlm.nih. gov/11248153/.

13. Eichhorn PJA, Gili M, Scaltriti M, Serra V, Guzman M, Nijkamp W, et al. Phosphatidylinositol 3-kinase hyperactivation results in lapatinib resistance that is reversed by the mTOR/phosphatidylinositol 3-kinase inhibitor NVPBEZ235. Cancer Res. 2008:68:9221-30 [cited 2021 Apr 18]. Available from: https://pubmed.ncbi.nIm.nih.gov/19010894/.
14. O'Reilly KE, Rojo F, She QB, Solit D, Mills GB, Smith D, et al. mTOR inhibition induces upstream receptor tyrosine kinase signaling and activates Akt. Cancer Res. 2006;66:1500-8 [cited 2021 Apr 18]. Available from: https:// pubmed.ncbinlm.nih.gov/16452206/.

15. García-García C, Ibrahim YH, Serra V, Calvo MT, Guzmán M, Grueso J, et al. Dual mTORC1/2 and HER2 blockade results in antitumor activity in preclinical models of breast cancer resistant to anti-HER2 therapy. Clin Cancer Res. 2012;18:2603-12 [cited 2021 Apr 18]. Available from: https:// pubmed.ncbi.nlm.nih.gov/22407832/.

16. Ibrahim YH, García-García C, Serra V, He L, Torres-Lockhart K, Prat A, et al. PI3K inhibition impairs BRCA1/2 expression and sensitizes BRCA-proficient triple-negative breast cancer to PARP inhibition. Cancer Discov. 2012;2: 1036-47 [cited 2021 Apr 18]. Available from: https://pubmed.ncbi.nIm.nih. gov/22915752/.

17. Serra V, Scaltriti M, Prudkin L, Eichhorn PJA, Ibrahim YH, Chandarlapaty S, et al. PI3K inhibition results in enhanced HER signaling and acquired ERK dependency in HER2-overexpressing breast cancer. Oncogene. 2011;30: 2547-57 [cited 2021 Apr 18]. Available from: https://pubmed.ncbi.nlm.nih. gov/21278786/

18. Serra V, Markman B, Scaltriti M, Eichhorn PJA, Valero V, Guzman M, et al. NVP-BEZ235, a dual PI3K/mTOR inhibitor, prevents PI3K signaling and inhibits the growth of cancer cells with activating PI3K mutations. Cancer Res. 2008;68:8022-30 [cited 2021 Apr 18]. Available from: https:/pubmed. ncbi.nlm.nih.gov/18829560/.

19. Elkabets $M$, Vora $S$, Juric $D$, Morse $N$, Mino-Kenudson $M$, Muranen $T$, et al. MTORC1 inhibition is required for sensitivity to PI3K p110a inhibitors in PIK3CA-mutant breast cancer. Sci Transl Med. 2013;5 [cited 2021 Apr 18]. Available from: https://pubmed.ncbi.nlm.nih.gov/23903756/.

20. Juric $D$, Castel $P$, Griffith $M$, Griffith OL, Won HH, Ellis H, et al. Convergent loss of PTEN leads to clinical resistance to a PI(3) Ka inhibitor. Nature. 2015; 518:240-4 [cited 2021 Apr 18]. Available from: https://pubmed.ncbi.nlm.nih. gov/25409150/.

21. Tao JJ, Castel P, Radosevic-Robin N, Elkabets M, Auricchio N, Aceto N, et al. Antagonism of EGFR and HER3 enhances the response to inhibitors of the PI3K-Akt pathway in triple-negative breast cancer. Sci Signal. 2014;7 [cited 2021 Apr 18]. Available from: https://pubmed.ncbi.nlm.nih.gov/24667376/.

22. Bosch A, Li Z, Bergamaschi A, Ellis H, Toska E, Prat A, et al. PI3K inhibition results in enhanced estrogen receptor function and dependence in hormone receptor-positive breast cancer. Sci Transl Med. 2015;7 [cited 2021 Apr 18]. Available from: https://pubmed.ncbi.nlm.nih.gov/25877889/.

23. Toska E, Osmanbeyoglu HU, Castel P, Chan C, Hendrickson RC, Elkabets M, et al. PI3K pathway regulates ER-dependent transcription in breast cancer through the epigenetic regulator KMT2D. Science (80- ). 2017;355:1324-30 [cited 2021 Apr 18]. Available from: https:/pubmed.ncbi.nlm.nih.gov/28336670/.

24. Arruabarrena-Aristorena A, Maag JLV, Kittane S, Cai Y, Karthaus WR, Ladewig E, et al. FOXA1 mutations reveal distinct chromatin profiles and influence therapeutic response in breast cancer. Cancer Cell. 2020;38:534-550.e9 [cited 2021 Apr 18]. Available from: https:/pubmed.ncbin.nlm.nih.gov/32888433/.

25. Castel P, Ellis H, Bago R, Toska E, Razavi P, Carmona FJ, et al. PDK1-SGK1 signaling sustains AKT-independent mTORC1 activation and confers resistance to PI3Ka inhibition. Cancer Cell. 2016;30:229-42 [cited 2021 Apr 18]. Available from: https://pubmed.ncbi.nlm.nih.gov/27451907/.

26. Toska E, Castel P, Chhangawala S, Arruabarrena-Aristorena A, Chan C, Hristidis VC, et al. PI3K inhibition activates SGK1 via a feedback loop to promote chromatin-based regulation of ER-dependent gene expression. Cell Rep. 2019;27:294-306.e5 [cited 2021 Apr 18]. Available from: https:// pubmed.ncbinlm.nih.gov/30943409/.

27. Elkabets M, Pazarentzos E, Juric D, Sheng Q, Pelossof RA, Brook S, et al. AXL mediates resistance to PI3Ka inhibition by activating the EGFR/PKC/mTOR Axis in head and neck and esophageal squamous cell carcinomas. Cancer Cell. 2015;27:533-46 [cited 2021 Apr 18]. Available from: https://pubmed. ncbi.nlm.nih.gov/25873175/.

28. Zumsteg ZS, Morse N, Krigsfeld G, Gupta G, Higginson DS, Lee NY, et al. Taselisib (GDC-0032), a potent $\beta$-sparing small molecule inhibitor of PI3K, radiosensitizes head and neck squamous carcinomas containing activating PIK3CA alterations. Clin Cancer Res. 2016;22:2009-19 [cited 2021 Apr 18]. Available from: https://pubmed.ncbi.nlm.nih.gov/26589432/.

29. Castel P, Carmona FJ, Grego-Bessa J, Berger MF, Viale A, Anderson KV, et al. Somatic PIK3CA mutations as a driver of sporadic venous malformations. Sci Transl Med. 2016;8 [cited 2021 Apr 18]. Available from: https://pubmed.ncbi. nlm.nih.gov/27030594/. 
30. von Minckwitz G, Procter M, de Azambuja E, Zardavas D, Benyunes M, Viale $\mathrm{G}$, et al. Adjuvant Pertuzumab and Trastuzumab in early HER2-positive breast cancer. N Engl J Med. 2017;377:122-31 [cited 2021 Apr 22]. Available from: https://pubmed.ncbi.nlm.nih.gov/28581356/

31. Hyman DM, Puzanov I, Subbiah V, Faris JE, Chau I, Blay J-Y, et al. Vemurafenib in multiple nonmelanoma cancers with BRAF V600 mutations. N Engl J Med. 2015;373:726-36 [cited 2021 Apr 22]. Available from: https:// pubmed.ncbi.nlm.nih.gov/26287849/.

32. Raje N, Chau I, Hyman DM, Ribrag V, Blay J-Y, Tabernero J, et al. Vemurafenib in patients with relapsed refractory multiple myeloma harboring BRAF V600 mutations: a cohort of the histology-independent VEBASKET study. 2018;2:1-9 [cited 2021 Apr 22]. Available from: https:// pubmed.ncbi.nlm.nih.gov/32913989/.

33. Shukla N, Roberts SS, Baki MO, Mushtaq Q, Goss PE, Park BH, et al. Successful targeted therapy of refractory pediatric ETV6-NTRK3 fusionpositive secretory breast carcinoma. JCO Precis Oncol. 2017;2017:1-8 [cited 2021 Apr 22]. Available from: https://pubmed.ncbi.nlm.nih.gov/29623306/.

34. Razavi P, Chang MT, Xu G, Bandlamudi C, Ross DS, Vasan N, et al. The genomic landscape of endocrine-resistant advanced breast cancers. Cancer Cell. 2018;34:427-438.e6 [cited 2021 Apr 18]. Available from: https:// pubmed.ncbi.nlm.nih.gov/30205045/.

35. Vasan N, Razavi P, Johnson JL, Shao H, Shah H, Antoine A, et al. Double PIK3CA mutations in cis increase oncogenicity and sensitivity to PI3Ka inhibitors. Science (80- ). 2019;366:714-23 [cited 2021 Apr 18]. Available from: https://pubmed.ncbi.nlm.nih.gov/31699932/.

\section{Publisher's Note}

Springer Nature remains neutral with regard to jurisdictional claims in published maps and institutional affiliations.

Ready to submit your research? Choose BMC and benefit from:

- fast, convenient online submission

- thorough peer review by experienced researchers in your field

- rapid publication on acceptance

- support for research data, including large and complex data types

- gold Open Access which fosters wider collaboration and increased citations

- maximum visibility for your research: over $100 \mathrm{M}$ website views per year

At $\mathrm{BMC}$, research is always in progress.

Learn more biomedcentral.com/submissions 